THE QUALITY OF GROWTH IN AFRICA

INITIATIVE FOR POLICY DIALOGUE AT COLUMBIA: CHALLENGES IN DEVELOPMENT AND GLOBALIZATION 


\section{INITIATIVE FOR POLICY DIALOGUE AT COLUMBIA: \\ CHALLENGES IN DEVELOPMENT \\ AND GLOBALIZATION}

\section{JOSÉ ANTONIO OCAMPO AND JOSEPH E. STIGLITZ, SERIES EDITORS}

Escaping the Resource Curse, Macartan Humphreys, Jeffrey D. Sachs, and Joseph E. Stiglitz, eds.

The Right to Know, Ann Florini, ed.

Privatization: Successes and Failures, Gérard Roland, ed.

Growth and Policy in Developing Countries: A Structuralist Approach, José Antonio Ocampo, Codrina Rada, and Lance Taylor

Taxation in Developing Countries, Roger Gordon, ed.

Reforming the International Financial System for Development, Jomo Kwame Sundaram, ed.

Development Cooperation in Times of Crisis, José Antonio Ocampo and José Antonio Alonso

New Perspectives on International Migration and Development, Jeronimo Cortina and Enrique Ochoa-Reza, eds.

Industrial Policy and Economic Transformation in Africa, Akbar Noman and Joseph E. Stiglitz, eds.

Macroeconomics and Development: Roberto Frenkel and the Economics of Latin America, Mario Damill, Martín Rapetti, and Guillermo Rozenwurcel, eds.

Too Little, Too Late: The Quest to Resolve Sovereign Debt Crises, Martin Guzman, José Antonio Ocampo, and Joseph E. Stiglitz, eds.

Efficiency, Finance, and Varieties of Industrial Policy:

Guiding Resources, Learning, and Technology for Sustained Growth, Akbar Noman and Joseph E. Stiglitz, eds.

The Welfare State Revisited, José Antonio Ocampo and Joseph E. Stiglitz, eds. International Policy Rules and Inequality: Implications for Global Economic Governance, José Antonio Ocampo, ed. 


\title{
THE QUALITY OF GROWTH IN AFRICA
}

\author{
tortro or \\ Ravi Kanbur, Akbar Noman, \\ and Joseph E. Stiglitz
}

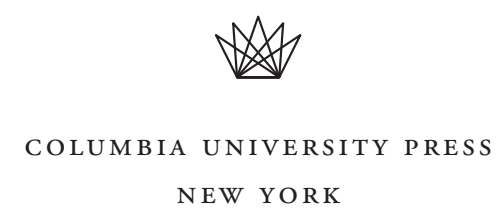

NEW YORK 


\section{Columbia University Press}

Publishers Since 1893

New York Chichester, West Sussex

cup.columbia.edu

Copyright ( 2019 Columbia University Press

All rights reserved

Library of Congress Cataloging-in-Publication Data

A complete CIP record is available from the Library of Congress.

ISBN 978-0-231-19476-1 (cloth : alk. paper)

ISBN 978-0-231-55098-7 (e-book)

Columbia University Press books are printed on permanent and durable acid-free paper.

Printed in the United States of America

Cover image: Lost Horizon Images/Cultura/Getty Images 


\section{INITIATIVE FOR POLICY DIALOGUEAT COLUMBIA: \\ CHALLENGES IN DEVELOPMENT \\ AND GLOBALIZATION \\ JOSÉ ANTONIO OCAMPO AND JOSEPH E. STIGLITZ, SERIES EDITORS}

The Initiative for Policy Dialogue (IPD) at Columbia University brings together academics, policy makers, and practitioners from developed and developing countries to address the most pressing issues in economic policy today. IPD is an important part of Columbia's broad program on development and globalization. The Initiative for Policy Dialogue at Columbia: Challenges in Development and Globalization presents the latest academic thinking on a wide range of development topics and lays out alternative policy options and tradeoffs. Written in a language accessible to policy makers and students alike, this series is unique in that it both shapes the academic research agenda and furthers the economic policy debate, facilitating a more democratic discussion of development policies.

The quality of economic growth has been at the center of global debates in recent years. This book focuses on how those concerns pertain to and are reflected in Africa (mainly South of the Sahara). Several research and policy issues around the quality of growth have arisen in the region after the resumption of economic growth in the 1990s following a long period of stagnation or decline in much of it.

The authors in this volume examine a range of interrelated concerns that fall under the general heading of the quality of growth. These include: (i) the distribution of the income gains from growth; (ii) the translation of economic growth into nonincome dimensions of wellbeing such as employment, health, education and security; (iii) the structural transformation of the economy so that the sources of growth and employment are diversified away from dependence on low-productivity primary commodities and informal activities towards modern manufacturing (including "industrialized agriculture") and services; (iv) managing the urbanization process so it enhances the quality of life; and (v) environmental sustainability. 
